\title{
Fenugreek: A Miraculous Medicinal Herb
}

\author{
Tariq Ahmad Dar ${ }^{1,2 *}$ and Moin Uddin ${ }^{2}$ \\ ${ }^{1}$ Plant Physiology and Biochemistry Section, Department of Botany, Aligarh Muslim University, India \\ ${ }^{2}$ Government Degree College for Women Pulwama, University of Kashmir, Hazratbal Srinagar (J \& k), India
}

Submission: November 01, 2017; Published: August 24, 2018

*Corresponding author: Tariq Ahmad Dar, Government Degree College for Women, Pulwama (J \& K), University of Kashmir, Hazratbal, Srinagar, India, Tel: +91 9419167391; Email: dartariq21@gmail.com

\begin{abstract}
Trigonella foenum-graecum L. commonly known as Fenugreek belongs to family Fabaceae. Fenugreek is both a spice and a medicinal plant, used from times immemorial by human beings as a vegetable and against various ailments and diseases. Fenugreek seeds are known to contain about $45.4 \%$ dietary fiber, alkaloids (Diosgenin and Trigonelline), saponins, aminoacds, vitamins and minerals. The plant seeds and extracts are specifically used against hyperglycaemia, hypercholesterolemia and as galactogogue. The saponins produced from fenugreek are used industrially to prepare different types of steroidal drugs.

Trigonella foenum-graecum L. commonly known as Fenugreek is native to Southern Europe, the Mediterranean region and Western Asia and is an annual herb of family Fabaceae. Fenugreek is locally known as Methi and is cultivated throughout India for a vegetable, culinary and medicinal purposes. It is also grown as fodder. This plant is well known for its miraculous medicinal properties. The plant extract is anti-allergic [1], antipyretic [2], anti-diabetic [3,4], anti-cholestrolemic [5], anti-malarial, antioxidant [6], and anti-cancerous [7,8]; it cures anaemia and respiratory disorders [9], relieves skin irritation and is used in the treatment of indigestion and flatulence [10]. It is an immunomodulatory agent and is also used as galactogogue [11]. Medicinal properties of fenugreek can be attributed to its bioactive constituents like 4-hydroxyisoleucine (4-HI), trigonelline, galactomannans, diosgenin, flavonoids, carotenoids, coumarins, proteins, saponins and lipids. Fenugreek seeds act as dietary supplement and significantly reduce the symptoms of diabetes mellitus (DM) such as polydipsia, polyuria, urine sugar, renal hypertrophy and glomerular filtration rate [12]. Fenugreek seed-alkaloid, known as trigonelline (Figure 1) controls diabetes mellitus through operation of the mechanism of insulin secretion, modulation of $\beta$-cell regeneration and stimulation of activity of glucose metabolism related enzymes [13,14].
\end{abstract}

Keywords: Fenugreek; Trigonella foenum-graecum; Galactogogue; Diosgenin and trigonelline

Abbrevations: NaAD: Nicotinateadenine Nucleotide; NaMN: Nicotinate Mononucleotide; NaR: Nicotinateriboside; NMN: Nicotinamide Mononucleotide; NR: Nicotinamideriboside; PPi: Pyrophosphate; PRPP: 5-Phosphoribosyl-1-Pyrophosphate; DM: Diabetes Mellitus; SAM: S-Adenosyl-L-Methionine; PNC: Pyridine Nucleotide Cycle

\section{Constituents of Fenugreek and their uses}

Saponins are amphipathic glycosides having hydrophilic glycoside moieties combined with a lipophilic triterpene derivative. The glycoside free (aglycone) portion of the saponin is termed as sapogenins. There are different sources of saponins and one of the chief source is fenugreek. Fenugreek contains approximately 4 to $8 \%$ saponins and about $1 \%$ alkaloids. The main steroidal sapogenins obtained from fenugreek seeds are diosgenin and yamogenin which are used as steroid intermediates in the pharmaceutical industry. The occurrence of diosgenin [(25R)-spirost-5-en-3 $\beta$-ol] in the seeds of fenugreek has been well expected for over 50 years [15]. Other saponins and steroidal saponins present in fenugreek include fenugrin $B$, fenugreekine, trigofoenosides A-G, tigogenin, neotigogenin, gitogenin, neogitogenin, yuccagenin and saponaretin [16]. The plant alkaloid Trigonelline (0.3-0.4\%) was first isolated from the seeds of fenugreek. it is a pyridine alkaloid, known for its hypoglycaemic and hypocholesterolemic activity. Trigonelline ( $\mathrm{N}$-methylnicotinic acid) is derived from nicotinic acid and the reaction is catalysed by S-adenosyl-L-methionine (SAM)dependent nicotinate enzyme $\mathrm{N}$-methyltransferase. Nicotinamide and nicotinic acid, the products of pyridine nucleotide cycle (PNC) give rise to trigonelline. The synthesis of trigonelline from nicotinamide mononucleotide (NaMN) is shown in the Figure 2. Other alkaloids present $\mathrm{n}$ fenugreek include Choline, Gentianine, Carpaine and Betain [16-18].

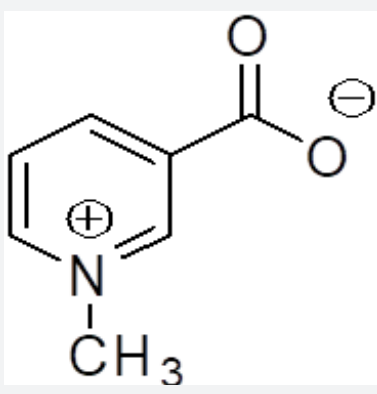

Figure 1: Structure of trigonelline. 


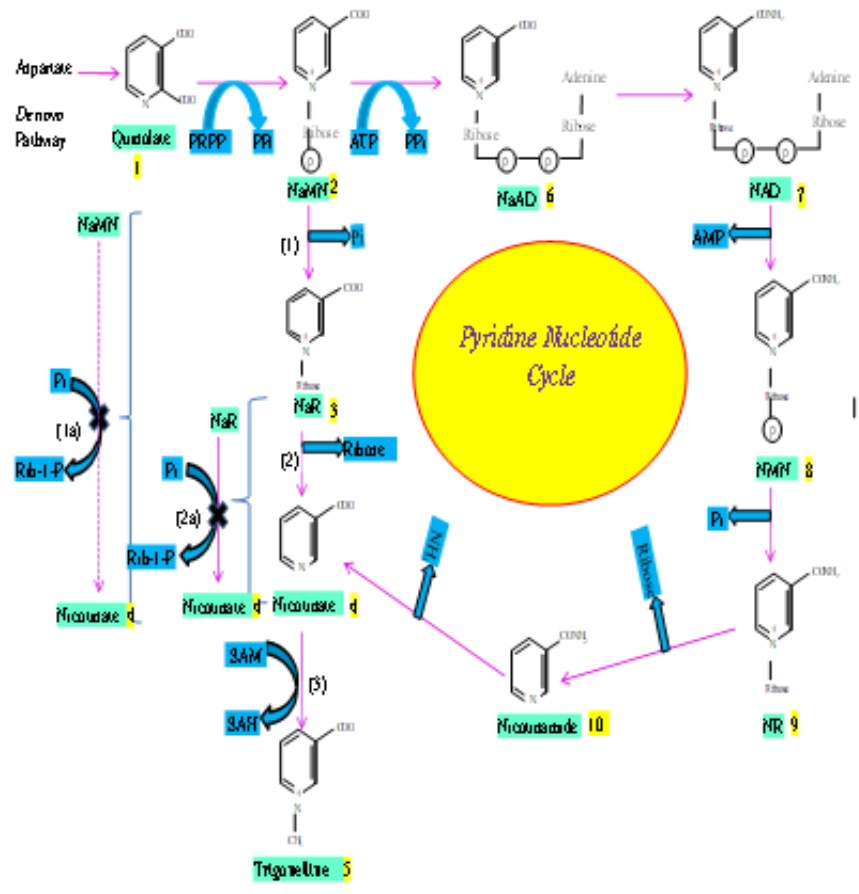

Figure 2: Proposed pathway of trigonelline (5) synthesis from NaMN (2). Steps 1-3 are respectively catalysed by NaMNnucleotidase, $\mathrm{NaRnucleosidase}$ and trigonelline synthase. The alternative enzymes, nicotinatephosphoribosyltransferase or NaMNglycohydrolase (reaction is not shown), might participate in the step 1a, and nucleoside phosphorylase in step 2a, although no evidence was obtained here. Trigonelline (5) synthesis via the pyridine nucleotide cycle is also shown.

Various amino acids have been found to be present in fenugreek which includes 4-Hydroxyisoleucine, Histidine, L-tryptophan, Argenine, Isoleucine, Leucine and lysine [19]. Flavonoids constitute about $100 \mathrm{mg} / \mathrm{g}$ of fenugreek seed such as such as apigenin, luteolin, orientin, quercetin, vitexin and isovitexin [20,21]. Fenugreek is abundant in polyphenolic compounds. 4-Hydroxyisoleucine (4-OH-Ile) is known to be present only in plants and is particularly plentiful in the seeds of fenugreek, where it comprises almost $80 \%$ of the total content of free amino acids. The amino acid, 4-OH-Ile stimulates the release of insulin and controls blood sugar levels [3].

The seeds of fenugreek are rich source of vitamins namely choline, vitamin A, B1, B2, C, nicotinic acid and niacin, biotin, calcium pantothenate, pyridoxine, vitamin $\mathrm{C}$ and cyanocobalamine [22]. They also contain significant amount of minerals like sulphur, phosphorus [23] and calcium [24]. Besides above, fenugreek contains a lot of other useful products and compounds like fiber (galactomannans), natural antioxidants and flavonoids etc [25-27].

\section{References}

1. Thiel RJ (1997) Effects of naturopathic interventions on symptoms associated with seasonal allergic rhinitis. American Naturopathic Medical Association Monitor 1: 4-9.

2. Ahmadiani A, Javan M, Semnanian S, Bharat E, Kamalinejad M (2001) Anti-inflammatory and antipyretic effects of Trigonella foenumgraecum leaves extract in the rat. J Ethnopharmacol 75: 283-286.
3. Gupta A, Gupta R, Lal B (2001) Effect of Trigonella foenum graecum (fenugreek) seeds on glycaemic control and insulin resistance in type 2 diabetes mellitus: A double-blind placebo controlled study. Journal of Association of Physicians of India 49: 1057-1061.

4. Kumar GS, Shetty AK, Sambaiah K, Salimath PV (2005) Antidiabetic property of fenugreek seed mucilage and spent turmeric in streptozotocin-induced diabetic rats. Nutrition Research 25(11): 1021-1028.

5. Hannan JM, Rokeya B, Faruque O, Nahar N, Mosihuzzaman M, et al (2003) Effect of soluble dietary fibre fraction of Trigonella foenumgraecum on glycemic, insulinemic, lipidemic and platelet aggregation status of Type 2 diabetic model rats. J Ethnopharmacol 88: 73-77.

6. Madhava NM, Shyamala BN, Pura NJ, Sulochanamma G, Srinivas PS (2011) Chemical composition and antioxidant activity of the husk and endosperm of fenugreek seeds. LWT - Food Science Technol 44(2): 451-456.

7. Khoja KK, Shaf G, Hasan TN, Syed NA, Al-Khalifa AS, et al. (2011) Fenugreek, a naturally occurring edible spice, kills MCF-7 human breast cancer cells via an apoptotic pathway. Asian Pac J Cancer Prev 12(12): 3299-3304.

8. Alsemari A, Alkhodairy F, Aldakan A, Al-Mohanna M, Bahoush E, et al. (2014) The selective cytotoxic anti-cancer properties and proteomic analysis of Trigonella foenum-graecum. BMC complementary and alternative medicine 14(1): 114.

9. Kaviarasan S, Vijayalakshmi K, Anuradha C V (2004) Polyphenol-rich extract of fenugreek seeds protect erythrocytes from oxidative damage. Plant Foods for Human Nutrition 59(4): 143-147.

10. Sauvaire Y, Ribes G, Baccou JC, Loubatieres-Mariani MM (1991) Implication of steroid saponins and sapogenins in the hypocholesterolemic effect of fenugreek. Lipids 26(3): 191-197. 
11. Gaby MP (2002) Galactagogues: medications that induce lactation. Journal of Human Lactation 18(3): 274-279.

12. Ulbricht C, Basch E, Burke D, Cheung L, Ernst E, et al. (2007) Fenugreek (Trigonella foenum-graecum L. Leguminosae): an evidence-based systematic review by the natural standard research collaboration. J Herb Pharmacother 7(3-4): 143-177.

13. Hamza N, Berke B, Cheze C, Le Garrec R, Umar A, et al. (2012) Preventive and curative effect of Trigonella foenum-graecum L. seeds in C57BL/6] models of type 2 diabetes induced by high-fat diet. J Ethnopharmacol 142: 516-522.

14. Zhou J, Chan L, Zhou S (2012) Trigonelline: A plant alkaloid with therapeutic potential for diabetes and central nervous system disease. Curr Med Chem 19(21): 3523-3531.

15. Marker RE, Wagner RB, Ulshafer PR, Wittbecker EL, Goldsmith PPJ, et al. (1947) New sources for sapogenins. J Am Chem Soc 69(9): 2242.

16. Yadav R, Kaushik R (2011) A study of phytochemical constituents and harmacological actions of Trigonella foenum-graecum: A review. Int J Pharm Technol 3: 1022-1028.

17. Kaviarasan S, Naik G, Gangabhagirathi R, Anuradha C, Priyadarsini $\mathrm{K}$ (2007) In-vitro studies on antiradical and antioxidant activities of fenugreek (Trigonella foenum graecum) seeds. Food Chem 103(1): 31 37.

18. Rababah TM, Ereifej KI, Esoh RB, Al-u'datt MH, Alrababah MA, et al. (2011) Antioxidant activities, total phenolics and HPLC analyses of the phenolic compounds of extracts from common Mediterranean plants. Nat Product Res 25(6): 596-605.

This work is licensed under Creative

Commons Attribution 4.0 License

DOI: 10.19080/JCMAH.2018.07.555710
19. Ruby B, Gaskill S, Slivka D, Harger S (2005) The addition of fenugreek extract (Trigonella foenum-graecum) to glucose feeding increases muscle glycogen resynthesis after exercise. Amino Acids 28(1): 71-76.

20. Naidu MM, Shyamala B, Naik JP, Sulochanamma G, Srinivas P (2011) Chemical composition and antioxidant activity of the husk and endosperm of fenugreek seeds. LWT-Food Sci Technol 44(2): 451-456.

21. Sauvare Y, Pett P, Baissao Y, Ribes G (2000) Chemistry and pharmacology of fenugreek. In G. Mazza \& B. D. Oomah (Eds.), Herbs, botanicals and teas. PA, USA: Technomic Publishing Company Inc, pp. 107-129.

22. Leela N, Shafeekh K (2008) Fenugreek, Chemistry of Spices. CAB International, Pondicherry, India.

23. El Nasri NA, El Tinay A (2007) Functional properties of fenugreek (Trigonella foenum graecum) protein concentrate. Food Chem 103(2): 582-589.

24. Jani R, Udipi S, Ghugre P (2009) Mineral content of complementary foods. The Indian J. Pediatrics 76(1): 37-44.

25. Zheng XQ Matsui A, Ashihara H (2008) Biosynthesis of trigonelline from nicotinate mononucleotide in mungbean seedlings. Phytochemistry 69(2): 390-395.

26. Gupta S, Prakash J (2009) Studies on Indian green leafy vegetables for their antioxidant activity. Plant Foods for Human Nutrition 64(1): 3945 .

27. Kuhn A, Gerhard H (1943) The trigonellin and nicotinic acid content of seeds of fenugreek. Arch Pharm U Ber Deutsch Pharm Ges 281: 378 379.

\section{Your next submission with Juniper Publishers will reach you the below assets}

- Quality Editorial service

- Swift Peer Review

- Reprints availability

- E-prints Service

- Manuscript Podcast for convenient understanding

- Global attainment for your research

- Manuscript accessibility in different formats

(Pdf, E-pub, Full Text, Audio)

- Unceasing customer service

Track the below URL for one-step submission

https://juniperpublishers.com/online-submission.php 